\title{
BUDAYA MENGAITKAN BERBAGAI PERISTIWA DENGAN HALMISTIS OLEH MASYARAKAT INDONESIA
}

\author{
Felicia Justine, Karina Jodie, Muhammad Rafi Alfajri, Muhammad Syakir A.R.U. Dilo, \& \\ Zidan Hidayat Al Kautsar \\ Institut Teknologi Bandung \\ Email: karina.jodie@gmail.com
}

\begin{abstract}
Abstrak
Sudah banyak sekali kejadian-kejadian menghebohkan yang terjadi di Indonesia, mulai dari bencana alam, kecelakaan, hingga kematian figur publik. Kejadian-kejadian yang terjadi di Indonesia ini seringkali dikaitkan dengan hal-hal mistis oleh masyarakat indonesia. Dari hal ini, dilakukan penelitian dengan mengandalkan pendekatan kuantitatif berdasarkan data yang diambil menggunakan kuesioner. Penelitian ini akan menjawab pertanyaan "Apa yang menyebabkan masyarakat masih mengaitkan suatu peristiwa dengan hal-hal yang berbau mistis?", "Apa dampak yang terlihat akibat masyarakat masih mempercayai hal-hal tersebut?", "Apakah hal ini merupakan hal yang positif atau negatif?". Ketika mendengar suatu hal yang mistis banyak orang-orang yang takut untuk melakukan hal-hal yang tidak senonoh seperti membuang sampah, berkata-kata yang tidak sopan, berbuat asusila dan sebagainya. Tetapi banyak masyarakat yang tidak mau mendengar hasil investigasi dari para ahli karena sudah mendengar cerita turun-temurun dari keluarga dan orangorang disekitarnya. Maka dapat disimpulkan bahwa kebiasaan mengaitkan fenomena dengan hal mistis ini memiliki dampak baikdan dampak buruk di saat yang bersamaan.
\end{abstract}

Kata kunci : Mistis, Budaya, Indonesia

\begin{abstract}
There have been so many events that have occurred in Indonesia, ranging from natural disasters, accidents, to the death of public figures. The events that occur in Indonesia are often associated with mystical things by the Indonesian people. From this, research is carried out by relying on a quantitative approach based on data taken using a questionnaire. This study will answer the questions "What causes people to associate an event with mystical things?", "What is the impact of believing in mythical things?", "Is this a positive or negative trend?". When hearing something mystical, many people are scared to do indecent things, such as littering, saying impolite words, doing immoral things and so on. But many people won't believe the results of experts because they have heard stories passed down from generation to generation from their families and people around them. So it can be concluded that the habit of associating phenomena with mystical things has both good and bad effects at the same time.
\end{abstract}

Keywords : Mystic, Culture, Indonesia

\section{PENDAHULUAN}

Indonesia adalah negara dengan ragam jenis budaya. Menurut CNN Indonesia, berdasarkan sensus BPS 2010, Indonesia memiliki lebih dari 300 kelompok etnis atau 1340 kelompok suku bangsa. Dengan banyaknya etnis dan suku budaya, tentu banyak juga budaya di Indonesia. Budaya disini bukan hanya seputar adat turun-temurun, tapi juga sesuatu yang diciptakan oleh akal pikiran (Rachman et al., 2021).

Seorang ahli bernama Ralph Linton memberikan definisi kebudayaan sebagai seluruh cara kehidupan dari masyarakat dan tidak hanya mengenai sebagian tata cara hidup saja yang dianggap lebih tinggi dan lebih diinginkan. Jadi, kebudayaan menunjuk pada berbagai aspek kehidupan, meliputi cara-cara berlaku, kepercayaan, sikap dan hasil kegiatan manusia yang khas untuk suatu masyarakat atau kelompok penduduk tertentu (Zainal, 2016) (Dewantara \& Nurgiansah, 2021a). Salah satu kepercayaan dalam masyarakat adalah percaya akan hal-hal mistis. 
Kepercayaan akan hal mistis seperti turun-temurun dalam masyarakat. Hal-hal mistis diantaranya cerita makhluk ghaib (seperti pocong, kuntilanak, atau penampakan arwah gentayangan), kejadian atau kemampuan di luar nalar (seperti ilmu kebal atau ilmu hitam), atau mitos atau legenda yang beredar di masyarakat (mitos dilarang bersiul di malam hari dan legenda Nyi Roro Kidul di Pantai Selatan Jawa). Terdapat juga berbagai pekerjaan-pekerjaan yang berkaitan dengan hal-hal mistis seperti dukun, paranormal, atau pemangku adat (dimana hal-hal mistis termasuk dalam suatu adat tertentu). Tak jarang juga halhal mistis dikaitkan dengan berbagai benda (seperti keris, sesajen) atau tempattempat seperti rumah sakit, jembatan, tempat wisata, dll. Hal-hal mistis juga sering dikaitkan dengan berbagai peristiwa seperti bencana alam, fenomena alam atau fenomena sosial.

Seperti yang disebutkan sebelumnya, berbagai fenomena sosial dikaitkan hal-hal mistis, contoh kecelakaan di Jalan Tol Cipularang, Kecelakaan Bus di Sukabumi, dan yang terbaru yaitu kecelakaan yang menewaskan Vanessa Angel dan suaminya, yang memunculkan banyak teori konspirasi. Hal ini menunjukkan betapa banyaknya budaya yang mengaitkan berbagai peristiwa dengan hal-hal mistis, dan penelitian ini bertujuan untuk membahas seputar kepercayaan masyarakat tentang budaya mengaitkan hal-hal mistis oleh masyarakat Indonesia.

Berdasarkan latar belakang diatas, maka dapat disimpulkan bahwa perumusan masalah dari penelitian ini adalahh apa yang menyebabkan masyarakat masih mengaitkan suatu peristiwa dengan hal-hal yang berbau mistis? apa dampak yang terlihat akibat masyarakat masih mempercayai hal-hal tersebut? dan apakah hal ini merupakan hal yang positif atau negatif?
Tujuan yang hendak dicapai melalui penulisan laporan penelitian ini adalah untuk mengetahui pandangan masyarakat terhadap budaya orang Indonesia yang suka mengaitkan kejadian-kejadian yang terjadi dengan hal-hal mistis dan mencari tahu dampak dari mempercayai hal-hal mistis dari budaya orang Indonesia yang suka mengaitkan kejadian-kejadian yang terjadi dengan hal-hal mistis.

Pada karya tulis ini, ada beberapa manfaat yang dapat diambil. Adapun manfaat-manfaat tersebut antara lain: mengambil sisi positif dan negatif dari adanya kepercayaan masyarakat terhadap hal mistis yang dihubungkan pada suatu peristiwa yang terjadi dan mendapatkan wawasan serta pandangan baru mengenai alasan serta latar belakang adanya kepercayaan masyarakat terhadap hal mistis yang dihubungkan pada suatu peristiwa yang terjadi.

\section{METODE PENELITIAN}

Pada penelitian ini, metode penelitian yang digunakan adalah dengan pendekatan kuantitatif. Pendekatan kuantitatif merupakan metode penelitian dengan data yang berdasarkan pada analisis-analisis yang dapat diukur dan merujuk kepada fakta yang nyata (Dewantara \& Nurgiansah, 2021b). Setelah itu, jika data-data sudah terkumpul maka data akan dianalisis untuk mencari jawaban dari permasalahan yang menjadi topik dari pembahasan penelitian ini.

Data yang diperlukan pada penelitian ini merupakan data yang berasal dari analisis nyata maka itu teknik pengumpulan data yang digunakan adalah dengan menggunakan kuesioner. Hal ini dilakukan dengan cara menyebarkan kuesioner yang terdiri dari beberapa pertanyaan mengenai topik permasalahan ini. Kuesioner yang telah dibuat disebarkan kepada responden lewat beberapa platform media sosial yang ada.

Pada penelitian ini, kuesioner yang 
disebarkan dibuat menggunakan Google Form. Alasan dipilih untuk menggunakan Google Form adalah karena pembuatan kuesioner dan penyebarannya sangat sederhana dan mudah. Dengan cepat, kuesioner tersebut dapat sampai ke responden yang dituju. Setelah kuesioner sudah diisi oleh responden, data - datanya tersimpan dengan aman dan mudah untuk dianalisis sebab data yang disajikan oleh Google Form sudah berupa diagram atau persentase. Selain itu membuat kuesioner di Google Form juga tidak membutuhkan biaya.

\section{HASIL PENELITIAN DAN PEMBAHASAN Pengertian Hal Mistis}

Mistis merupakan suatu pengetahuan yang tidak rasional dan bebas dari ketergantungan indera dan rasio, mistis merupakan sebuah pengetahuan yang diperoleh tidak melalui indera dan bukan melalui rasio. Pengetahuan mistis ini diperoleh melalui rasa dan hati. Objek pengetahuan mistis pada umumnya berupa objek yang abstrak-supra-rasional yang contohnya seperti Tuhan, malaikat, surga, neraka, jin, dan alam gaib (Nurgiansah, 2020b).

Pengetahuan mistis memiliki cara ukur masing-masing dalam pengukuran kebenarannya, salah satu ukuran kebenaran dari pengetahuan mistis adalah berupa kepercayaan yang jika digunakan maka pengetahuan mistis tersebut dianggap benar jika kita mempercayainya. Ada juga cara mencapai kebenaran melalui bentuk bukti empiris, yang jika digunakan maka pengetahuan mistis tersebut akan sulit dipahami jika tidak memiliki bukti empiris dan akan sulit juga diterima secara rasional (Nurgiansah, 2021).

Pengetahuan mistis sangatlah subjektif, yang paling mengerti cara menggunakannya hanyalah pemiliknya, di kalangan sufi, kegunaanya dapat menentramkan jiwa mereka, mereka menggunakan pengetahuan mistis untuk kebaikan, di balik itu ada juga mistis magis hitam, dinamakan magis hitam karena tujuan penggunaannya adalah untuk kejahatan. Penggunaan pengetahuan mistis dalam menyelesaikan masalah tidak melewati proses inderawi dan juga tidak melalui proses rasio. (Hambali,2011) (Nurgiansah, 2020a)

\section{Kepercayaan Mistis di Indonesia}

Indonesia adalah negara dengan beragam budaya dengan berbagai kepercayaan mistis seperti mitos, legenda, dan hal mistis lainnya yang turut mempengaruhi seseorang dalam berperilaku. Meskipun Indonesia berpenduduk mayoritas Muslim yang seharusnya lebih paham mengenai baikburuknya mempercayai suatu hal mistis selain yang dijelaskan dalam kepercayaannya. Keyakinan mistis yang berkembang di masyarakat di antaranya yaitu tidak boleh duduk di depan pintu 2 karena akan sulit jodoh, tidak boleh membuka payung di dalam rumah karena akan membawa sial dan kepercayaan lainnya. Mempercayai sesuatu yang irasional tersebut bisa disebut dengan kepercayaan mistis. Kepercayaan mistis adalah keyakinan irasional bahwa suatu objek, tindakan, atau keadaan yang tidak terkait secara logis dengan suatu peristiwa dapat mempengaruhi hasilnya. (Damisch et al., 2010).

Kepercayaan mistis yang paling umum dan berkembang di indonesia adalah kepercayaan mengenai dukun, penerawang/medium, benda keramat, larangan, mitos, dan ritual. Kepercayaankepercayaan ini dapat terus lestari akibat sifatnya yang menyebar secara menjaring dari orang ke orang. Eksposur lewat media pun turut menjaga eksistensi dari kepercayaan mistis di Indonesia, baik media amatir maupun media nasional tidak jarang memberikan sorotan terhadap hal mistis. 
Kepercayaan mistis di Indonesia berkembang secara kedaerahan sehingga setiap daerah memiliki kepercayaannya masing-masing. Contohnya di daerah Pantai Selatan Jawa, terdapat kepercayaan terhadap Nyi Roro Kidul, daerah Kalimantan dengan sihir, dan Badui dengan ilmu kebal. Urbanisasi yang telah terjadi selama ini membantu kepercayaan yang bersifat kedaerahan mendapat eksposur di lingkungan nasional, yang secara tidak langsung menyebarkan kepercayaan-kepercayaan tersebut.

Di Abad Ke-21, kepercayaan mistis masih tetap eksis di tengah modernisasi yang sedang berjalan secara global. Kepercayaan-kepercayaan mistis di Indonesia akan tetap bertahan selama masih ada individu atau kelompok yang mempraktekkan, menyaksikan, atau menyebarkannya ke masyarakat awam. Karena sifatnya yang kebanyakan tidak kasat mata dan cenderung menakutkan bagi masyarakat, kebanyakan dari masyarakat akan mudah percaya hanya dengan didasarkan dengan rasa takut tersebut. Namun, kelompok masyarakat yang sudah memiliki pendirian atau pemahaman mengenai subjek ini tidak akan dengan mudah atau tidak akan percaya sama sekali dengan hal mistis. Kejadian ini memberikan kemungkinan bahwa kepercayaan mistis akan hilang ketika semua orang sudah terpelajar dengan baik, dan tidak ada yang mempraktekkan lagi kepercayaankepercayaan yang ada.

\section{Pembahasan \\ Data Hasil Penelitian}

Pada penelitian ini, telah dibuat kuesioner yang berisi beberapa pertanyaan seputar kepercayaan serta cerita tentang hal mistis. Pertanyaan ada yang berbentuk pilihan ganda yang merupakan skala 1-5 dan ada yang berbentuk isian. Pertanyaanpertanyaan yang diajukan pada kuesioner antara lain sebagai berikut.

1. Seberapa percaya anda dengan hal-hal mistis? (skala 1-5)

2. Seberapa sering anda mendengar cerita-cerita mistis? (skala 1-5)

3. Boleh diceritakan singkat, cerita mistis apa itu? (isian)

4. Apakah anda percaya dengan hal tersebut? (ya, tidak, atau mungkin)

5. Apakah anda pernah mendengar cerita tentang suatu peristiwa yang dikaitkan dengan halmistis? (ya atau tidak)

6. Boleh diceritakan singkat tentang hal tersebut? (isian)

7. Apakah anda percaya dengan hal tersebut? (ya, tidak, atau mungkin)

8. Jika ada kewajiban yang harus dilakukan mengenai hal-hal yang berhubungan dengan hal mistis tersebut, apakah anda akan menaatinya? (ya, tidak, atau mungkin)

Setelah kuesioner disebar kepada masyarakat umum, didapatkan jawaban dari masyarakat dari berbagai suku, umur, maupun pekerjaan. Dalam kelompok umur, ada responden dengan rentang umur 1015 tahun, 15-20 tahun, 20-25 tahun, dan 25-30 tahun. Secara suku asal responden, ada yang merupakan masyarakat suku Jawa, Sunda, Tionghoa, Aceh, Madura, dan lain-lain. Secara pekerjaan, ada yang berprofesi sebagai pelajar/mahasiswa, dosen/guru, pegawai swasta, freelance, wirausahawan, dan perawat. Hasil respons yang diberikan oleh responden untuk setiap pertanyaan yang diajukan pada kuesioner dapat dilihat pada Gambar. 
Seberapa percaya anda dengan hal-hal mistis?

46 responses

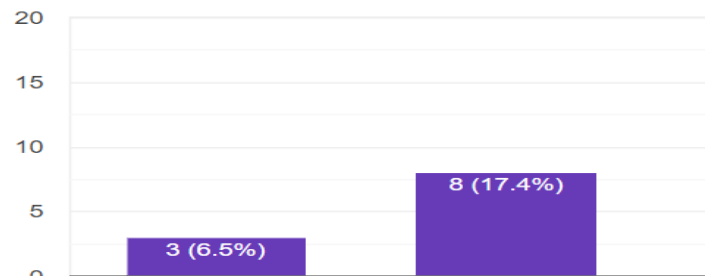

2

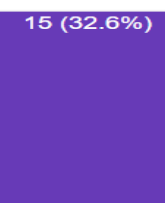

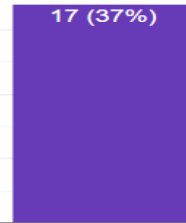

$3(6.5 \%)$

Gambar 4-1. Respons untuk pertanyaan "Seberapa percaya anda dengan hal-hal mistis?"

Seberapa sering anda mendengar cerita-cerita mistis?

46 responses

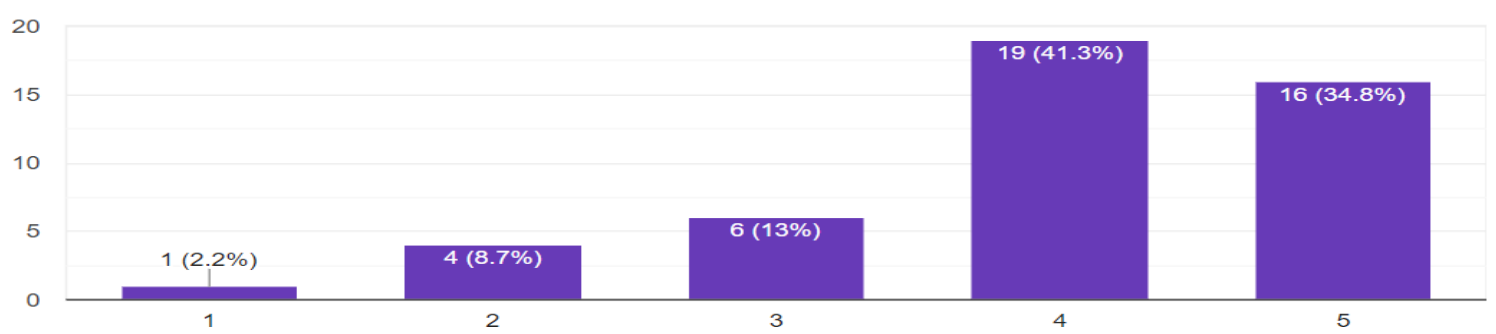

Gambar 4-2. Respons untuk pertanyaan "Seberapa sering anda mendengar cerita-cerita mistis?"

Apakah anda percaya dengan hal tersebut?

46 responses
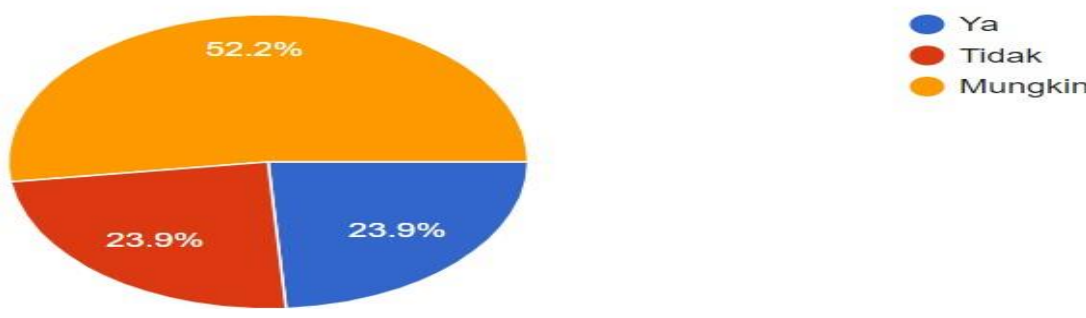

Gambar 4-3. Respons untuk pertanyaan “Apakah anda percaya dengan hal tersebut?” (merujuk pada pertanyaan sebelumnya) 
Apakah anda pernah mendengar cerita tentang suatu peristiwa yang dikaitkan dengan hal mistis?

46 responses
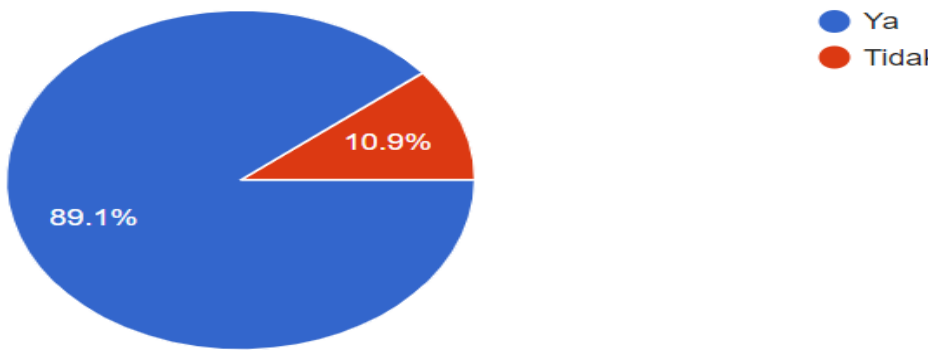

Gambar 4-4. Respons untuk pertanyaan “Apakah anda pernah mendengar cerita tentang suatu peristiwa yang dikaitkan dengan hal mistis?"

Apakah anda percaya dengan hal tersebut?

46 responses
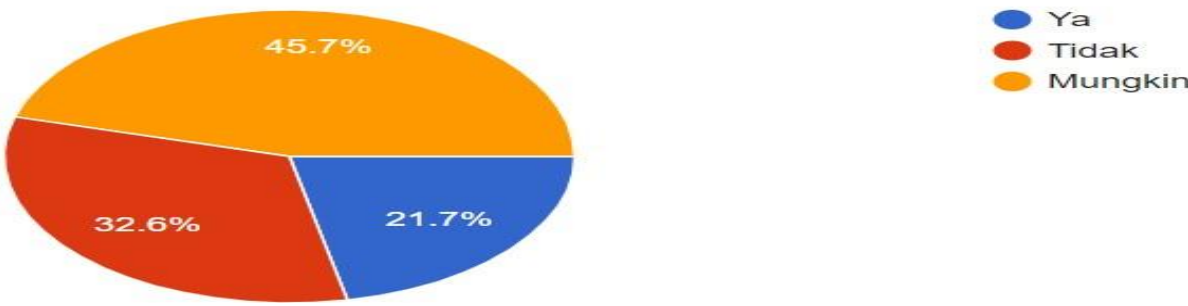

Gambar 4-5. Respons untuk pertanyaan “Apakah anda percaya dengan hal tersebut?” (merujuk pada pertanyaan sebelumnya)

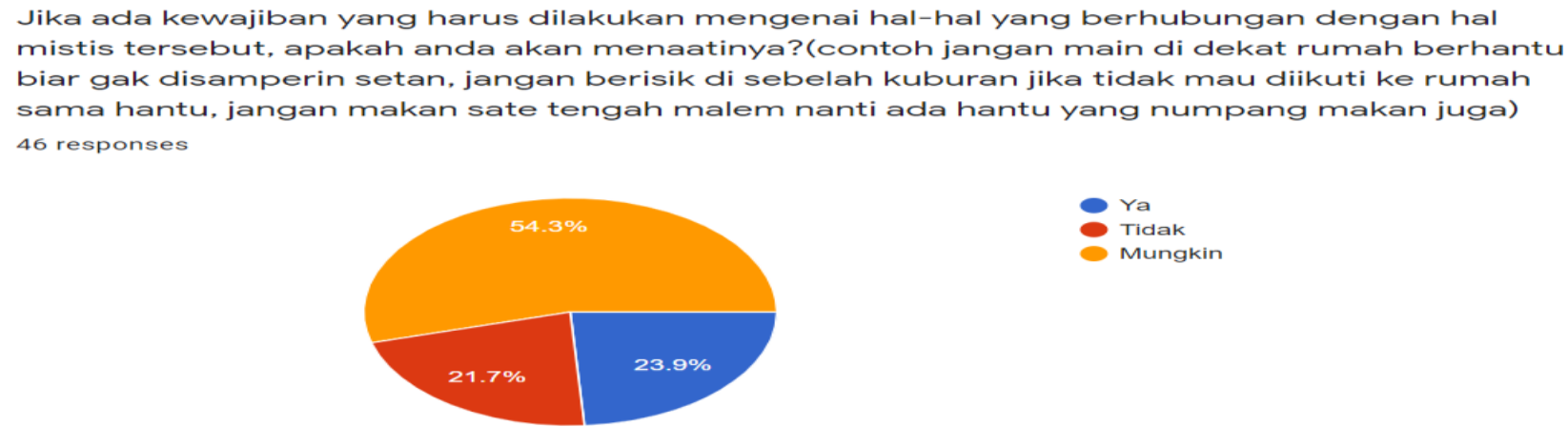

Gambar 4-6. Respons untuk pertanyaan "Jika ada kewajiban yang harus dilakukan mengenai hal-hal yang berhubungan dengan hal mistis tersebut, apakah anda akan menaatinya?"

Berdasarkan hasil respon dari penyebaran kuisioner yang telah dilakukan, dapat dilihat bahwa sebagian besar responden percaya dengan hal-hal mistis. Sebanyak 6.5\% responden mengatakan bahwa mereka sangat tidak percaya dengan hal mistis, $17.4 \%$ responden merasa tidak percaya, $32.6 \%$ responden merasa biasa saja, $37 \%$ responden merasa percaya, dan $6.5 \%$ orang merasa sangat percaya terhadap halhal mistis. Dari hasil ini menunjukkan 
bahwa kepercayaan masyarakat terhadap hal mistis masih terbilang tinggi. Hal ini dapat disebabkan karena beberapa hal, seperti pernah mengalami kejadian mistis secara langsung, pengaruh dari lingkungan, adanya kewajiban atau dorongan dari lingkungan untuk mempercayai hal-hal tersebut, dan lain-lain.

Kemudian, dapat diketahui juga bahwa hampir semua responden pernah mendengar atau mendapatkan cerita-cerita yang berbau mistis. $34.8 \%$ responden mengatakan sangat sering, $41.3 \%$ responden mengatakan sering, $13 \%$ responden mengatakan cukup sering, 8.7\% responden mengatakan jarang, dan 2.2\% responden mengatakan bahwa ia tidak pernah sama sekali mendengar cerita tentang hal-hal yang berbau mistis. Dari hasil jawaban kuisioner juga dapat diketahui cerita-cerita apa saja yang pernah didapatkan oleh responden. Adapun beberapa cerita yang pernah didapatkan atau didengar oleh responden antara lain:

1. Larangan menggunakan pakaian hijau ke pantai selatan Jawa karena nanti bisa diseret oleh Nyi Roro Kidul,

2. Banyaknya penunggu di alat musik gamelan,

3. Teman dekat dari salah satu responden pernah melihat tuyul di toilet kampus ternama,

4. Pelarisan bisnis dengan menggunakan jin,

5. Driver taksi membawa penumpang yang ternyata bukan manusia,

6. Sekolah-sekolah yang tanahnya merupakan bekas kuburan di masa lampau,

7. Larangan anak kecil keluar rumah saat maghrib karena berpotensi diculik oleh wewegombel,

8. Pohon pisang sarang makhluk halus,

9. dan lain-lain.

Dari beberapa hasil jawaban yang didapatkan ini, dapat diketahui bahwa masyarakat banyak mendapatkan ceritacerita berbau mistis yang mungkin belum pernah dibuktikan secara logika kebenarannya. Keberadaan seperti makhluk halus, wewe gombel, Nyi Roro Kidul, tuyul, dan lain-lain tidak dapat dilihat dengan mata normal manusia. Hanya manusia-manusia dengan kelebihan dalam hal indera yang dapat melihat secara langsung penampakan dari makhluk-makhluk tersebut. Dari hasil jawaban ini menunjukkan bahwa masyarakat di Indonesia masih banyak mendapatkan cerita-cerita mistis yang jenisnya sangat banyak dan bervariasi.

Di samping jawaban mengenai pengetahuan akan cerita mistis tersebut, dapat diketahui bahwa sebagian besar responden masih ragu-ragu untuk mengatakan bahwa ia percaya akan ceritacerita mistis yang pernah didapatkan, yaitu sebanyak 52.2\%. Di samping itu, 23.9\% mengatakan bahwa mereka percaya dengan cerita-cerita mistis yang pernah didengar dan 23.9\% lainnya mengatakan tidak percaya. Hal ini menunjukkan bahwa meskipun masyarakat sudah sering mendapatkan cerita-cerita tentang hal mistis, tetapi cerita tersebut tidak langsung dimakan mentah-mentah oleh sebagian besar orang tersebut. Pembuktian lebih lanjut sekiranya akan meyakinkan responden dan masyarakat untuk memilih percaya atau tidak akan cerita-cerita yang pernah diceritakan kepada mereka.

Kemudian, berdasarkan jawaban pertanyaan berikutnya, sebagian besar responden pernah mendapatkan cerita tentang suatu peristiwa yang dikaitkan dengan hal gaib, yaitu sebanyak $89.1 \%$ responden. Sisanya, $10.9 \%$ responden mengatakan bahwa mereka belum pernah mendengar hal semacam ini. Dari jawaban ini, dapat diketahui juga cerita-cerita apa yang pernah didengar oleh responden. Beberapa cerita tersebut antara lain:

1. Kejadian sebelas pelajar SMP meninggal karena tenggelam di sebuah 
sungai, namun ternyata sungai tersebut hanyalah sungai kecil, sehingga dikatakan bahwa ada makhluk yang menarik korban untuk masuk ke dalam sungai.

2. Pendaki yang hilang di gunung karena mengatakan hal-hal yang tidak sepantasnya dikatakan (berkata kotor/kasar).

3. Orang yang sedang sakit parah dikatakan ada kemungkinan bahwa ia telah disantet.

4. Terkena penyakit yang disebabkan karena "disapa" oleh makhluk halus atau pada daerahnya biasa disebut "Pidaraan". Saat siang sehat, saat malam banyak gejala aneh. Akhirnya dengan bantuan tetua setempat diberi pengobatan lalu menjadi sembuh.

5. Cuaca buruk yang dikaitkan dengan kemarahan makhluk tertentu.

6. Kecelakaan artis di jalan yang dikaitkan dengan gangguan makhluk halus atau "penunggu" di daerah tersebut.

7. Tumbal bangunan atau tumbal proyek.

8. Santri di pesantren yang membaca Surah Al-Jinn dalam Al-Quran pada malam tertentu lalu didatangi oleh jin tersebut.

9. dan lain-lain.

Dari beberapa hasil jawaban yang didapatkan ini, dapat diketahui bahwa masyarakat banyak mendapatkan ceritacerita tentang suatu peristiwa yang dikaitkan dengan hal-hal berbau mistis. Cerita-cerita ini bisa jadi ada yang sudah dibuktikan, tetapi ada juga yang mungkin belum dapat dipastikan kebenarannya. Hal ini dapat dikatakan demikian karena cerita yang didapatkan belum bisa diketahui kebenarannya. Ada kemungkinan itu hanyalah bualan dari pencerita. Akan tetapi, di samping itu juga tidak menutup kemungkinan bahwa cerita-cerita yang didapat adalah nyata adanya.

Di samping jawaban mengenai pengetahuan akan cerita tentang peristiwa yang dikaitkan dengan hal gaib, dapat dilihat berdasarkan hasil kuisioner bahwa sebagian besar responden masih merasa ragu-ragu untuk percaya terhadap ceritacerita yang pernah mereka dapatkan, yaitu sebesar $45.7 \%$. Di samping itu, $21.7 \%$ responden mengatakan bahwa mereka percaya dengan cerita-cerita yang pernah mereka dapatkan dan $32.6 \%$ mengatakan tidak percaya. Hal ini menunjukkan bahwa meskipun banyak yang sering mendengar cerita tentang peristiwa yang dikaitkan dengan hal gaib, masyarakat tidak langsung memakan mentah-mentah cerita yang mereka dapatkan. Ada beberapa alasan yang mungkin menyebabkan mereka tidak langsung percaya dengan hal tersebut, seperti membutuhkan pembuktian lebih lanjut, tidak ingin percaya dengan hal yang berhubungan dengan hal gaib, belum pernah merasakan peristiwa tersebut secara langsung, dan lain-lain. Pembuktian yang lebih valid sekiranya dapat meyakinkan masyakarat untuk memutuskan apakah percaya atau tidak dengan hal tersebut.

Terakhir, dari hasil respon untuk pertanyaan terakhir, dapat dilihat bahwa masih ragu-ragu untuk mengikuti atau menaati kewajiban yang harus dilakukan pada suatu tempat atau daerah mengenai hal-hal yang berhubungan dengan hal gaib atau mistis, yaitu sebesar 54.3\%. Di samping itu, $23.9 \%$ responden mengatakan akan menaati jika ada kewajiban akan hal tersebut dan 21.7\% mengatakan tidak akan menaatinya. Dari jawaban ini menunjukkan bahwa sebagian masyarakat masih ragu-ragu untuk menaati kewajiban-kewajiban yang sekiranya harus dilakukan pada suatu daerah mengenai hal mistis. Ada beberapa alasan yang mungkin menjadi jawaban akan alasan jawaban masyarakat, seperti tidak mengenal daerah yang mewajibkan hal tersebut, membutuhkan alasan konkrit untuk menaati hal tersebut, dan hal-hal lainnya. Begitu juga bagi masyarakat yang 
merasa akan menaati kewajiban-kewajiban tersebut jika ada, seperti karena sudah mengetahui sejarah akan kewajiban tersebut, pernah mengalami langsung halhal tersebut, menghargai aturan setempat, dan lain-lain.

Berdasarkan hasil jawaban secara keseluruhan, dapat dikatakan bahwa masyarakat sering dan banyak mendengar cerita-cerita tentang suatu hal atau peristiwa yang berkaitan dengan hal mistis yang jenisnya bermacam-macam. Akan tetapi, cerita-cerita tersebut tidak langsung dipercaya seluruhnya, masih banyak yang ragu-ragu untuk percaya akan cerita yang pernah mereka dengar. Dari hasil ini sekiranya kita sebagai masyarakat Indonesia perlu melakukan penyadaran lebih kepada masyarakat mengenai hal-hal yang berbau mistis. Tidak semua harus dipercaya karena belum dibuktikan kebenarannya secara konkrit. Bantuan dari masyarakat untuk mencerdaskan antarorang juga diperlukan agar masyarakat dapat lebih bijak dalam memilih percaya atau tidak terhadap halhal mistis. Tidak semua hal mistis adalah hal buruk, tidak menutup kemungkinan bahwa ada hal mistis yang membawa kita menuju kebaikan, seperti tidak boleh berkata kasar, berperilaku sopan santun pada suatu tempat, dan lain-lain. Penyelesaian masalah oleh orang-orang yang lebih ahli juga dapat menjadi solusi untuk lebih memilih untuk mempercayai hal yang berbau mistis, karena tidak semua kejadian atau masalah bisa dikaitkan dengan hal-hal mistis.

\section{KESIMPULAN}

Hasil pengamatan kami dari beberapa sumber ada dampak baik dan buruk mengenai hal ini. Dampak baik yang kita dapatkan adalah, ketika mendengar suatu hal yang mistis banyak orang-orang yang takut untuk melakukan hal-hal yang tidak senonoh seperti membuang sampah, berkata-kata yang tidak sopan, berbuat asusila dan sebagainya. Sedangkan dampak buruk yang didapatkan adalah banyak masyarakat yang tidak mau mendengar hasil investigasi dari para ahli karena sudah mendengar cerita turun-temurun dari keluarga dan orang-orang disekitarnya. Jika masyarakat masih percaya dengan hal ini maka akan ada banyak versi mengenai berbagai macam versi cerita dari suatu peristiwa dan pada akhirnya penjelasan para ahli akan dikesampingkan. Pada akhirnya masyarakat akan lebih percaya kepada cerita yang telah menyebar dari keluarga dan lingkungan sekitarnya.

Setelah melihat pemaparan dari kami yang diikuti eksperimen dari beberapa orang, kami berharap pembaca bisa mengambil sisi positif dari penjelasan makalah kami bahwa, tidak semua hal-hal yang diluar dugaan seperti kecelakaan, kaya mendadak, hilangnya orang, dsb. selalu berhubungan dengan hal mistis. Kita sebagai masyarakat yang bertanggungjawab sudah sepatutnya kita tidak dengan mudah menyebarkan berita yang tidak benar mengenai peristiwaperistiwa tertentu terutama menyambungkannya dengan hal-hal gaib, karena sebagian besar masyarakat terutama yang memiliki pengetahuan kurang/awam akan mudah percaya dengan mudah mengenai hal-hal tersebut, padahal tidak ada jaminan kebenarannya.

Penulisan makalah Budaya Mengaitkan Berbagai Peristiwa Dengan Hal Mistis Oleh Masyarakat Indonesia ini masih jauh dari kata sempurna. Penyusun berharap adanya kritik dan saran dari pembaca mengenai makalah ini.

\section{DAFTAR PUSTAKA}

Dewantara, J. A., \& Nurgiansah, T. H. (2021a). Peningkatan Keaktifan Belajar Melalui Penerapan Model Picture And Picture Dalam Pembelajaran PPKn di Sekolah Dasar. 
Jurnal Publikasi Pendidikan, 11(3), 234-241.

Dewantara, J. A., \& Nurgiansah, T. H. (2021b). Strengthening Pancasila Values During the Covid-19 Pandemic. Edukatif: Jurnal Ilmu Pendidikan, 3(4), 2411-2417.

Nurgiansah, T. H. (2020a). Fenomena Prostitusi Online Di Kota Yogyakarta Dalam Persfektif Nilai Kemanusiaan Yang Adil Dan Beradab. Jurnal Kewarganegaraan, 17(1), 27-34. https://doi.org/10.24114/jk.v17i1.14208

Nurgiansah, T. H. (2020b). Filsafat Pendidikan. In Banyumas: CV Pena Persada.

Nurgiansah, T. H. (2021). Pendidikan Pancasila. In Solok: CV Mitra Cendekia Media.

Rachman, F., Ryan, T., Kabatiah, M., Batubara, A., Pratama, F. F., \& Nurgiansah, T. H. (2021). Pelaksanaan Kurikulum PPKn pada Kondisi Khusus Pandemi Covid-19. Jurnal Basicedu, 5(6), 5682-5691.

Zainal, M. (2016). Studi tentang tradisi bunceng umat Konghucu di tempat ibadah Tri Dharma Kwan Sing Bio Tuban Jawa Timur. Surabaya: UIN Sunan Ampel Surabaya

https://www.beautynesia.id/berita-travel/5-hal-mistis-yang-sering-dipercava-di-indonesia/ b-119021

https://iurnal.ar-raniry.ac.id/index.php/substantia/article/download/4825/3112

https://www.tribunnews.com/regional/2021/11/22/nasib-yana-supriatna-setelah-ngeprank-hilang-di-cadas-pangeran-kini-jadi-tersangka-tidak-ditahan https://www.liputan6.com/global/read/2186908/8-3-2014-setahun-hilangnyamh370-dan-berbagai-teori-konspirasi

https://purwakarta.avoindonesia.com/berita-purwakarta/pr-32878471/Cerita-Mistis-Dibali k-Kecelakaan-Tol-Cipularang

https://www.jpnn.com/news/cerita-mistis-di-balik-kecelakaan-bus-di-sukabumi 